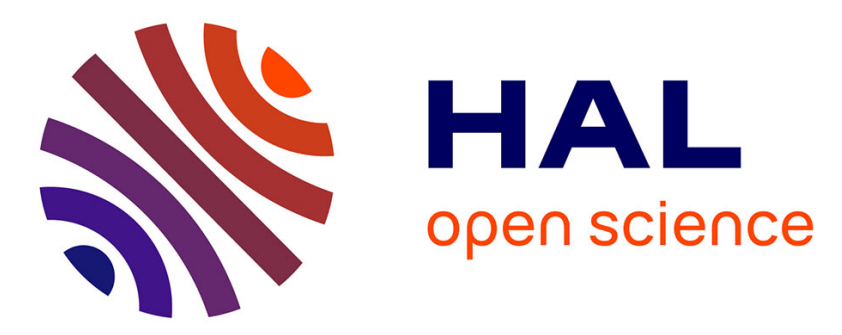

\title{
Symmetry of External Shock responses within the Andean Community of Nations: A SVAR Approach
}

Andrea Bonilla

\section{To cite this version:}

Andrea Bonilla. Symmetry of External Shock responses within the Andean Community of Nations : A SVAR Approach. 2012. halshs-00657939

\section{HAL Id: halshs-00657939 \\ https://shs.hal.science/halshs-00657939}

Preprint submitted on 9 Jan 2012

HAL is a multi-disciplinary open access archive for the deposit and dissemination of scientific research documents, whether they are published or not. The documents may come from teaching and research institutions in France or abroad, or from public or private research centers.
L'archive ouverte pluridisciplinaire HAL, est destinée au dépôt et à la diffusion de documents scientifiques de niveau recherche, publiés ou non, émanant des établissements d'enseignement et de recherche français ou étrangers, des laboratoires publics ou privés. 
Symmetry of External Shock responses within the Andean Community of Nations: A SVAR Approach

Andrea Gabriela Bonilla Bolaños

Décembre 2011 


\section{GATE Groupe d'Analyse et de Théorie Économique Lyon-St Étienne}

93, chemin des Mouilles 69130 Ecully - France

Tel. +33 (0)4 72866060

Fax $+33(0) 472866090$

6, rue Basse des Rives 42023 Saint-Etienne cedex 02 - France

Tel. +33 (0)4 77421960

Fax. $+33(0) 477421950$

Messagerie électronique / Email : gate@gate.cnrs.fr

Téléchargement / Download : http://www.gate.cnrs.fr - Publications / Working Papers 


\title{
Symmetry of External Shock responses within the Andean Community of Nations: A SVAR Approach
}

\author{
Andrea Gabriela Bonilla Bolaños \\ University of Lyon, Lyon, F-69003, France; University of Lyon2, Lyon, F-69007, France; CNRS, GATE \\ Lyon St Etienne, Ecully, F-69130, France. E-mail:bonilla@gate.cnrs.fr.
}

\section{August 2011}

\begin{abstract}
:
This article studies the symmetry in reactions of the Andean Community of Nations (CAN) economies to external shocks in order to analyze the group's evolution towards economic integration. The undertaking of a Monetary Union project in South America enhances the usefulness of evaluating shocks within this region according to the Optimal Currency Area Theory. A Structural VAR model with non-recursive contemporaneous restrictions is built for each economy and a correlation analysis is performed. The results evidence that the CAN has evolved positively towards structural convergence.
\end{abstract}

Keywords: Latin American countries, Monetary Union, OCA Theory, Structural VAR.

Mots-clefs: Pays Latino-Américaines, Union Monétaire, Théorie des ZMO, Modèle VAR Structurel.

JEL Classification: C32, E42, F41 


\section{Introduction}

The Treaty of Cartagena signed between Bolivia, Colombia, Ecuador and Peru created the Andean Community of Nations (CAN - Comunidad Andina de Naciones) in 1969 in order to improve their citizens' standard of living through the advantages of economic integration and social cooperation. The formal project started as a free trade agreement and evolved over time. During the 1990 's, the member countries envisaged a more ambitious process of integration and nowadays they have partially achieved a common market and take an active part in the Monetary Union project undertaken by the Union of South American Nations (UNASUR).

UNASUR is a new political and economic community that came into being in May 2008 with the intention to "integrate all South America ${ }^{1}$ in cultural, social, economic and political aspects" 2 by following the European Union model - including a common currency, parliament, and passport -. The aim to adopt a single currency within the South American continent began in September 2009 with the founding of the Bank of the South ${ }^{3}$ (BS), a bank created to finance the region's economic development projects and, in the future, to be responsible for common macroeconomic policy.

The feasibility of such a project depends on the fulfillment of several requirements. First, the Monetary Union (MU) is defined by the economic integration theory ${ }^{4}$ as the fourth of five steps preceded by: the establishment of a free trade area (FTA), the adoption of a custom union, and the abolition of mobility restrictions on goods, services and production factors -. Therefore, according to theoretical considerations, a group of countries must accomplish three steps before being able to form a Monetary Union. Moreover, the Optimal Currency Area (OCA) Theory establishes several criteria to be satisfied by a group of countries wishing to implement a common currency.

Several papers have empirically addressed MU aspects; however the South American case has only been partially studied. The literature assessing the region has focused only on Mercosur as a possible candidate to share a common currency, addressing the analysis from several approaches inter alia, the costs, benefits and performance of OCA criteria within the region (Eichengreen, 1998; Licandro Ferrado, 2000; Levy-Yeyati and Sturzenegger, 2000); lessons from the European Monetary Union from Mercosur (Arestis and Fernando de Paula, 2003; Levy-Yeyati and Sturzenegger, 2000), business cycle synchronization across countries and real and financial shock impact similarities

\footnotetext{
${ }^{1}$ UNASUR includes not only the two principal Latin American trading blocs - the CAN and Mercosur -, but also Chile, Surinam and Guyana (i.e., all South American countries).

2 UNASUR Constitutive Treaty, article 2

3 On 26 September 2009, the presidents of Argentina, Brazil, Paraguay, Uruguay, Ecuador, Bolivia and Venezuela signed an agreement establishing the South Bank with an initial capital of US\$20 billion. ("South American leaders sign agreement creating South Bank". MercoPress. 27 September 2009.)

${ }^{4}$ Balassa (1961)
} 
(Allegret and Sand 2006 and 2007; Gimet, 2007) and Mercosur's position with regard to a set of sustainability criteria (Gimet, 2008) - and concluding that implementing a common currency within this area is not viable. Moreover, the case of CAN countries is rarely envisaged to draw conclusions about MU Latin American aspects (Horchreiter and Siklos, 2002; Kopits, 2002, Hochreiter et al., 2002; Alesina and Barro, 2002; Alesina et al., 2003; Lopes and Tavares, 2003; Eichengreen and Taylor 2004). The partial or non-inclusion of CAN members in the analysis is important insofar as the bloc constitutes the second biggest trade area within the UNASUR, which is why this article focuses on the particular case of the Andean Community of Nations.

Regarding economic integration, since 1999, the CAN has committed itself to achieving a number of convergence goals ${ }^{5}$, inter alia, the gradual attainment of single-digit annual rates (inflation criteria - May 1999); a non-financial public sector deficit less than 3\% of GDP (fiscal convergence criteria - June 2001); and the harmonization of value-added type and indirect taxes (July 2004). This fact amplifies the importance of assessing the convergence of the bloc before and after the implementation of the above measures.

In this respect, this paper studies the symmetry in the responses of CAN economies to external shocks in two different periods of time (i.e., the 1990s and the 2000's) and compares them in order to evaluate the usefulness of the accepted convergence goals in the achievement of the integration objectives. It thus evaluates empirically the CAN's performance with regard to one specific OCA criterion: the "similarity of external shocks to which the different countries are exposed 6", part of the last phase of the OCA theory's literature - the "empirical phase" (Paolo, 2000). The high correlation of shocks among partners is a sign of structural convergence between countries, in fact, if the impact of shocks is similar throughout partner countries, then the need for policy autonomy $^{7}$ is reduced and the net benefits from adopting a single currency might be higher. By dealing with this issue, this article contributes to the assessment not only of the helpfulness of the measures implemented since 1999 by the CAN, but also of the convenience of the region adopting a common currency.

In this sense, this paper presents empirical evidence on the following questions: I) what are the responses of CAN economies to external shocks? And, II) are members' responses to external shocks similar within the CAN? The analysis proceeds in two stages: First, a SVAR model with short

\footnotetext{
${ }^{5}$ In 1997 the Ninth Andean Council of Presidents set up the Advisory Council to develop a working agenda for harmonizing the macroeconomic policies of the Andean Community Member Countries, but this was not launched until 1999.

${ }^{6}$ This criterion is important because "if the shocks are symmetric, then it was not necessary to change relative prices between the economies, therefore reducing the cost of giving up the exchange rate as an adjustment mechanism" (Paolo (2002)).

${ }^{7}$ Policy autonomy is lost when a country relinquishes its national currency to adopt a common one.
} 
run non-recursive contemporaneous restrictions is built for each CAN economy (i.e., Bolivia, Colombia, Ecuador and Peru) and for each period studied (i.e., the 1990s and the 2000's), and impulse - response functions are computed. Second, a correlation analysis of the responses of each country is performed to measure the symmetry between CAN members.

Several interesting facts emerge from the analysis. First, SVAR results evidence that CAN members' are more vulnerable to international shocks during the 2000's than during the 1990's. Second, the similarity of CAN economies' responses to external shocks has evolved positively after the commitment to convergence goals. Third, CAN economies' reactions are more similar in the face of a monetary policy shock than in the face of an international trade shock. And fourth, the internal subgroups, Ecuador-Bolivia and Colombia-Peru, present the highest co-movements. In general, this article empirically evidence that the CAN has evolved positively towards economic integration even if it cannot be concluded that the analyzed OCA criterion was achieved within the bloc.

The remainder of this paper is organized as follows: the next section presents the SVAR methodology and details the empirical formulation, section 3 discusses the results and, finally, section 4 concludes.

\section{The Econometric Framework: the SVAR Methodology}

The econometrical tool used by numerous empirical studies which analyze shocks impacts has usually been the Vector Autoregression Models (VAR), (inter alia, Calvo and Mendoza, 1998; Bordo and Murshid, 2002). However in recent years several authors have used Structural VAR models (SVAR) (Cushman and Tao, 1997; Kim and Roubini, 2000; Canova, 2005; Mackowiak, 2005; Gimet, 2007; Allegret and Sand, 2007) due to the fact that they make it possible to take into account the economic theory in modeling the countries' behavior and identify the shocks for a better interpretation of results. (See Appendix 1 for a formalization of the SVAR model).

In fact, SVAR models were introduced in the eighties in response to criticisms about the use of non-restricted VAR models to analyze the impulse propagation following Sims (1980) contribution.

Canonical innovations associated with non-restricted VAR models are shock or impulse propagations which translate into fluctuations of the dynamical system studied. These innovations must be contemporaneously uncorrelated in order to measure the contribution of each impulse to the dynamic of the system. However, VAR innovations are contemporaneously correlated; in other words, in VAR models, the shocks are not independent, thus it is not possible to isolate the effect of each one. 
Sims (1980) proposed a statistical orthogonalization method based on Choleski decomposition of error variance, to solve this problem, and, in this way, the recursive SVAR models came into being. Despite the advantages of recursive SVAR models, they had a disadvantage, the loss of economic simultaneity. Since then some other authors, Shapiro and Watson (1988) and Blanchard and Quah (1989), have proposed the presentation of economically identifiable innovations (demand shock, monetary shock, etc), a method that makes it possible to recover the simultaneity of the system. ${ }^{8}$

The above justify the choice of the SVAR approach as the most accurate for dealing with the issue tackled by this research.

\subsection{Empirical Formulation}

Consider that the economy is described by the structural form equation:

$$
B Y_{t}=\sum_{i=1}^{q} A_{i} Y_{t-i}+\varepsilon_{t}
$$

$\mathrm{B}$ is the contemporaneous interaction matrix ( $\mathrm{nxn}), \mathrm{A}$ is the dynamic interaction matrix (nxn), $\varepsilon_{t}$ represents the structural innovations vector ( $\left.\mathrm{nx} 1\right)$ and $\mathrm{q}$ is the number of retards. The structural innovations are supposed to be non-correlated (orthogonality assumption) and to have a unitary variance: $I_{n}=E\left(\varepsilon_{t} \varepsilon_{t}{ }^{T}\right){ }^{9}$ and the process is supposed stationary. The $\varepsilon_{t}$ innovations are identifiable "shocks" (i.e., inter alia, monetary policy shock, fiscal policy shock.)

The reduced form is represented by the canonical VAR model:

$$
Y_{t}=\sum_{i=1}^{q} \Phi_{i} Y_{t-i}+v_{t}
$$

Where $v_{t}$, the statistical innovations vector, is a white noise with variance - covariance $E\left(v_{t} v_{t}^{T}\right)=\Omega$ matrix which is not subject to the orthogonality restriction.

The moving average form of the canonical VAR model is:

$$
Y_{t}=\sum_{i=0}^{\infty} \Psi_{\mathrm{i}} v_{t-i}{ }^{10}
$$

\footnotetext{
8 Bruneau and Bandt 1998.

9 This assumption makes it possible to isolate the effects of the shocks, which is important for economic experimentation.

10 Derivation details in Appendix 1.
} 
The SVAR model and their canonical VAR representations are linked by $B v_{t}=\varepsilon_{t}(4)$. B is an invertible matrix $n x n$ which has to be estimated in order to identify the structural shocks. B is called the passage matrix and captures the contemporaneous restrictions - the short-run constraints are imposed directly on it corresponding to some elements of the matrix set to zero -.

As

$\operatorname{VAR}(\mathrm{p}): Y_{t}=\sum_{i=1}^{q} \Phi_{i} Y_{t-i}+v_{t}$ with $E\left(v_{t} v_{t}^{T}\right)=\Omega \quad\left(v_{t}\right.$ : statistical innovations $)$

$\operatorname{SVAR}(\mathrm{p}): B Y_{t}=\sum_{i=1}^{q} A_{i} Y_{t-i}+\varepsilon_{t}$ with $E\left(\varepsilon_{t} \varepsilon_{t}{ }^{T}\right)=I_{n}\left(\varepsilon_{t}\right.$ : structural innovations)

Then:

$$
\Omega=E\left(v_{t} v_{t}^{T}\right)=B E\left(\varepsilon_{t} \varepsilon_{t}^{T}\right) B^{T}=B B^{T}
$$

\subsubsection{Variables Choice}

The present Andean Community of Nations members - Bolivia, Colombia, Ecuador and Peru are studied in two different periods of time: 1993M1011 - 1999M12 and 2000M01 - 2010M12.1213 In order to measure the external shock impact on the real and monetary sector of each economy, four domestic variables (two real and two monetary) and two external shocks are selected.

In the model, each CAN economy is described by the endogenous variables vector:

$$
\Delta Y=\left(\begin{array}{l}
\Delta e x t \\
\Delta g d p \\
\Delta r e r \\
\Delta r \\
\Delta c p i
\end{array}\right)
$$

Where ext is the variable which represents external shocks, $g d p$ is the real gross domestic product $^{14}$, rer is the real exchange rate (indirect quotation), $r$ is deposit short run interest rate (monetary policy tool) ${ }^{15}$, and $c p i$ is the consumer prices index.

\footnotetext{
11 The 1990's period starts in 1993M10 due to unavailability of reliable data.

12 All variables are monthly except for the GDP which is quarterly. Data interpolation (quarterly to monthly) was performed with the quadratic math sum method (fix a local quadratic polynomial for each quarterly observation and then use this polynomial to fill in all observations of the monthly frequency)

${ }^{13}$ The data sources are the International Monetary Fund, Inter-American Development Bank and each country's Central Bank.

${ }^{14}$ For Colombia the gross domestic product is replaced by the Production Index for the period 1990-1999 due to the lack of data for that specific period.

15 This is a reasonable assumption for CAN's countries because Colombia and Peru are formally in a kind of inflation targeting; Ecuador, due to dollarization, cannot print money and it could be said that her only monetary policy tool is the interest rate.
} 
The choice of variables is the traditional one for SVARs analyzing external shocks ${ }^{16}$. The first two domestic variables (i.e., real gross domestic product and real exchange rate) are representative of the real economic sector, and the last two (i.e., the interest rate and consumer price index) represent the monetary sector. To take into account the supply and demand side, this choice follows the supply, demand and monetary shocks decomposition proposed by Gali (1992), Cushman and Zha (1997), Kim and Roubini (2000), and Mackowiak (2006). The aim of including the monetary and real sector at the same time is to take into consideration the fact that policymakers' reactions to shocks are different according to the existing exchange rate regimen and monetary policy objectives - the choice of variables makes it possible to differentiate between fixed and float exchange rates and inflation or monetary aggregate target -.

In this respect, the structural shocks vector is represented by:

$$
\varepsilon_{t}=\left(\begin{array}{c}
\varepsilon_{e x t} \\
\varepsilon_{G D P} \\
\varepsilon_{R E E R} \\
\varepsilon_{R} \\
\varepsilon_{I P C}
\end{array}\right)
$$

Where $\varepsilon_{e x t}$ is the external shock, $\varepsilon_{G D P}$ is a real supply domestic shock, $\varepsilon_{R E E R}$ is a real demand domestic shock, $\varepsilon_{R}$ is a money supply domestic shock (monetary policy shock) and $\varepsilon_{I P C}$ is a money demand domestic shock ${ }^{17}$.

The two selected external shocks, captured by the variable ext, are increased commodity prices $\left(P_{-} E X T\right)$, in view of the fact that CAN members are mainly commodity producers, and a positive innovation in USA interest rates (R_USA), taking into account the historical dependence of CAN economies on the United States. In fact, Bolivia, Colombia, Ecuador and Peru have been catalogued as commodity producers due to the enormous share - more than $60 \%$ for the four countries - of their oil, agricultural and mining sectors relative to their total exports (See Figure A.II). Moreover, the United States through the International Monetary Fund (IMF) have financed several of the CAN member's projects, thus creating very early on in the independent republican life of these countries a tradition of economic dependence on the USA.

Theoretically, a positive variation of commodity prices (positive international trade shock) directly affects each country's GDP. When commodity prices rise, the net exports of commodity

16 Cushman and Tao (1997), Canova (2005), Gimet 2007, Mackowiak (2005), Kim and Roubini (2000) and Allegret and Sand (2007)

17 To summarize, the shocks identification follows Gimet, 2007, except for the money demand domestic shock that follows Gali's 1992 identification. 
producers also rise, increasing aggregate demand and augmenting domestic production and price levels (AD-AS model theory). Changes in interest and exchange rates will depend on each country's monetary policy objective and the exchange rate regimen at the time.

On the other hand, an increase in USA rates causes depreciation of domestic currencies (Kim and Roubini, 2000). If depreciation is not possible, because of fixed rates or currency board agreements, the price level of Latin American securities should increase thus improving local interest rates. If the exchange rate adjusts fully and instantaneously, no changes in macroeconomic variables should be observed. When this is not the case, CAN members' output and prices may react (Canova, 2005). The domestic variables' reactions to a positive USA interest rate shock depend on the international integration degree of CAN economies as well as on the existing exchange rate regimen.

With regard to this, sixteen Structural VAR models are estimated independently: one for each CAN economy (four CAN members), for each external shock (two external shocks), and, for each of the two periods analyzed.

All variables were transformed into logarithms except for the domestic and USA interest rates and they were seasonally adjusted if required. The usual unit root test (Dickey-Fuller) concludes that some variables are stationary in level I(0) and some in first difference form I(1) as resumed in tables A.3.1. and A.3.2.

The multivariate analysis of cointegration rank, according the Johansen methodology, confirms the existence of cointegration relations between variables in some models ${ }^{18}$. To be econometrically rigorous, Structural VECMs (Vector Error Correction Models) are performed for those for which the Johansen test confirmed cointegration of variables (See appendix 2 for a formalization of SVECM procedure).

The SVARs or SVECMs order was defined by the known criteria (Akaike, Schawartz, Hanna) and the model validation tests were done. According to the tests, the dynamics are well described by SVARs(1) and SVECMs(1). ${ }^{19}$

\subsubsection{Model Identification: Short-run restrictions}

This study analyzes the economies' responses to external shocks in the short-term, and therefore, only contemporaneous restrictions are imposed. The objective is to identify $n^{2}$ elements of passage matrix (B). As $\Omega$ matrix is symmetrical $n(n+1) / 2$ restrictions are already defined and one

\footnotetext{
18 All the tests are available upon request to the author.

${ }^{19}$ All the tests are available upon request to the author.
} 
must impose only $n(n-1) / 2$ restrictions to achieve model identification. This particular case requires the imposition of 10 restrictions; for this purpose, the economic literature will be referred to.

The following equations summarize the identification scheme based on equation (4): $B V_{t}=$ $\varepsilon_{t}$.which links the statistical $\left(V_{t}\right)$ and the structural innovations $\left(\varepsilon_{t}\right)$.

$$
\left(\begin{array}{lllll}
1 & \mathbf{0} & \mathbf{0} & \mathbf{0} & \mathbf{0} \\
\mathrm{b}_{21} & 1 & \mathrm{~b}_{23} 20 & \mathbf{0} & \mathbf{0} \\
\mathrm{b}_{31} & \mathrm{~b}_{32} & 1 & \mathbf{0} & \mathbf{0} \\
\mathrm{b}_{41} & \mathbf{0} & \mathrm{b}_{43} & 1 & \mathbf{0} \\
\mathrm{b}_{51} & \mathrm{~b}_{52} & \mathrm{~b}_{53} & \mathrm{~b}_{54} & 1
\end{array}\right) \quad\left(\begin{array}{l}
\mathrm{V}_{\mathrm{ext}} \\
\mathrm{V}_{\mathrm{GDP}} \\
\mathrm{V}_{\mathrm{REER}} \\
\mathrm{V}_{\mathrm{R}} \\
\mathrm{V}_{\mathrm{IPC}}
\end{array}\right)=\left(\begin{array}{l}
\varepsilon_{\mathrm{ext}} \\
\varepsilon_{\mathrm{GDP}} \\
\varepsilon_{\mathrm{REER}} \\
\varepsilon_{\mathrm{R}} \\
\varepsilon_{\mathrm{IPC}}
\end{array}\right)
$$

First, following Mackowiak (2006) and Cushman and Zha (1997), CAN countries are supposed to be small open economies; therefore the external variables are exogenous $\left(b_{12}=b_{13}=b_{14}=b_{15}=0\right)$. Furthermore, as in Kim and Roubini (2000), the interest rate is assumed to be the reaction function of the monetary authority, which, due to informational ${ }^{21}$ and decisional ${ }^{22}$ lags, cannot respond contemporaneously to changes in price and output (Gali, 1992) $\left(b_{42}=b_{45}=0\right)$. Moreover, and again following Gali (1992), output is assumed not to respond to monetary policy shocks within a period $\left(b_{24}=0\right)$. Finally, as in Kim and Roubini, (2000), the model specification assumes that real activity $(G D P$ and $R E R)$ responds to price and financial signals (interest rate) only with a lag $\left(b_{25}=b_{34}=b_{35}=\right.$ $0) .23$

\section{Results Interpretations}

\subsection{External Shock Impacts into each CAN's Country}

Results are displayed in Figures 1, 2, 3 and 4; they illustrate the responses of domestic variables to a one standard deviation variation of the external variables. Error bands for Impulse Responses are computed with the Asymptotic Method ${ }^{24}$, and Impulse Response graphs contain the plus/minus two standard error bands about the impulse responses. A response is significant if its

\footnotetext{
${ }^{20}$ Note that it is a non-recursive system (i.e., it is not exactly a Choleski decomposition).

${ }^{21}$ Information delays means that data on output and prices is not available within a period according to Sims and Zha (1995), Gali (1992) and Kim and Roubini (2000).

${ }^{22}$ This assumption is enhanced in CAN countries because of the governments' influence on the monetary authority. CAN countries' Central Banks are not completely independent and therefore it takes time to approve a policy decision (Gali, 1992).

${ }^{23}$ The monthly data periodicity makes it possible to be sufficiently precise about the non contemporaneous reaction assumptions. Once all the required restrictions have been defined, it is possible to compute the structural innovations and interpret them.

${ }^{24}$ The asymptotic method relies on a delta expansion of the asymptotic distribution of the impulse response estimator (see Lutkepohl (1990, p. 118) and Mittnik and Zadrozny (1993)).
} 
computed error band does not include the zero. Tables 1 and 2 display the variance decomposition. The following is a short-term analysis: the responses correspond to differentiated variables ${ }^{25}$ and the imposed restrictions, in the non-restricted SVAR, are short-term ones.

\subsubsection{A commodity price shock}

CAN economies are commodity producers; therefore, a variation in commodity prices (international trade shock) directly affects their GDP. If commodity prices rise, the net exports of commodity producers also rise, raising aggregate demand and, consequently, production and price levels increase (AD-AS model theory). Changes in interest and exchange rates will depend on each country's monetary policy objective and exchange rate regimen (See Table A.I ${ }^{26}$ )
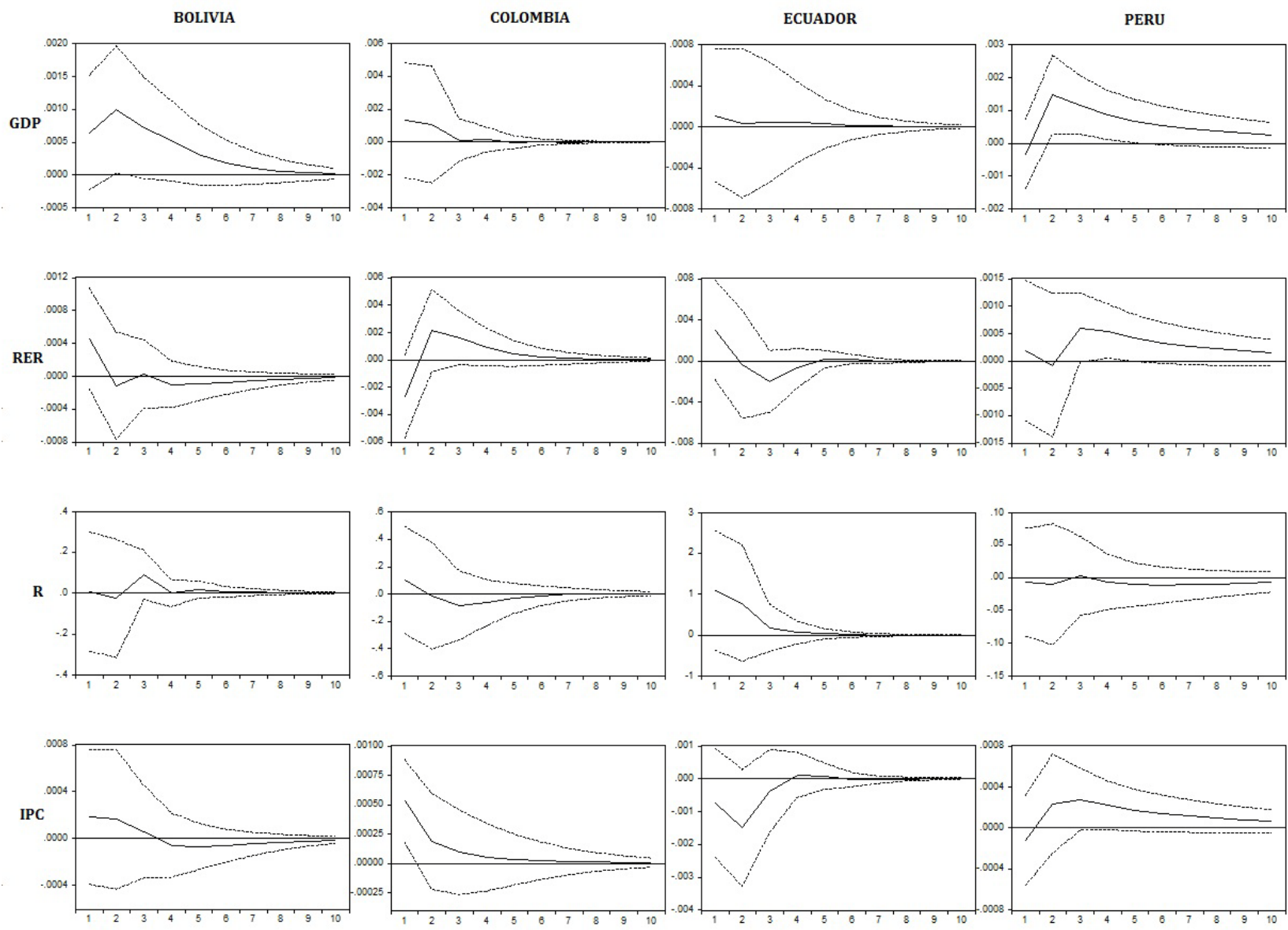

Figure 1. Impulse Response Functions to a Commodity Prices Shock during the period 1993-200027

${ }^{25}$ Included variables are I(1); therefore, to achieve SVAR stability, it is necessary to work with differentiated variables (stationary variables I(0)). Theoretically, a stationary variable responds only temporarily to shocks; thus, when working with differentiated variables, the responses will be short-term ones.

${ }^{26}$ In Appendix 4.

${ }^{27}$ Impulse-response figures have been obtained from SVAR models computed with monthly data which sources are the International Monetary Fund, Inter-American Development Bank and each country's Central Bank. 
As illustrated in Figure 1.28, during the 1990's Bolivia and Peru's output (GDP) responds positively and significantly to the shock (i.e., respectively the $7 \%$ and $12 \%$ of their output fluctuation is explained by the shock, as illustrated in Table 1), while Ecuador and Colombia's output does not react; this lack of reaction is explained by the El Niño-Southern Oscillation ${ }^{29}$, which mostly hit these two countries in the last quarter of 1997 and the first 5 months of 1998 leaving severe losses in the agricultural sector ${ }^{30}$. Bolivia's price levels (CPI) do not react, meaning that the boost in aggregate demand affects production more than prices (Canova 2005); in contrast, Peruvian ones do, reducing competitiveness (real exchange rate (RER) appreciation).
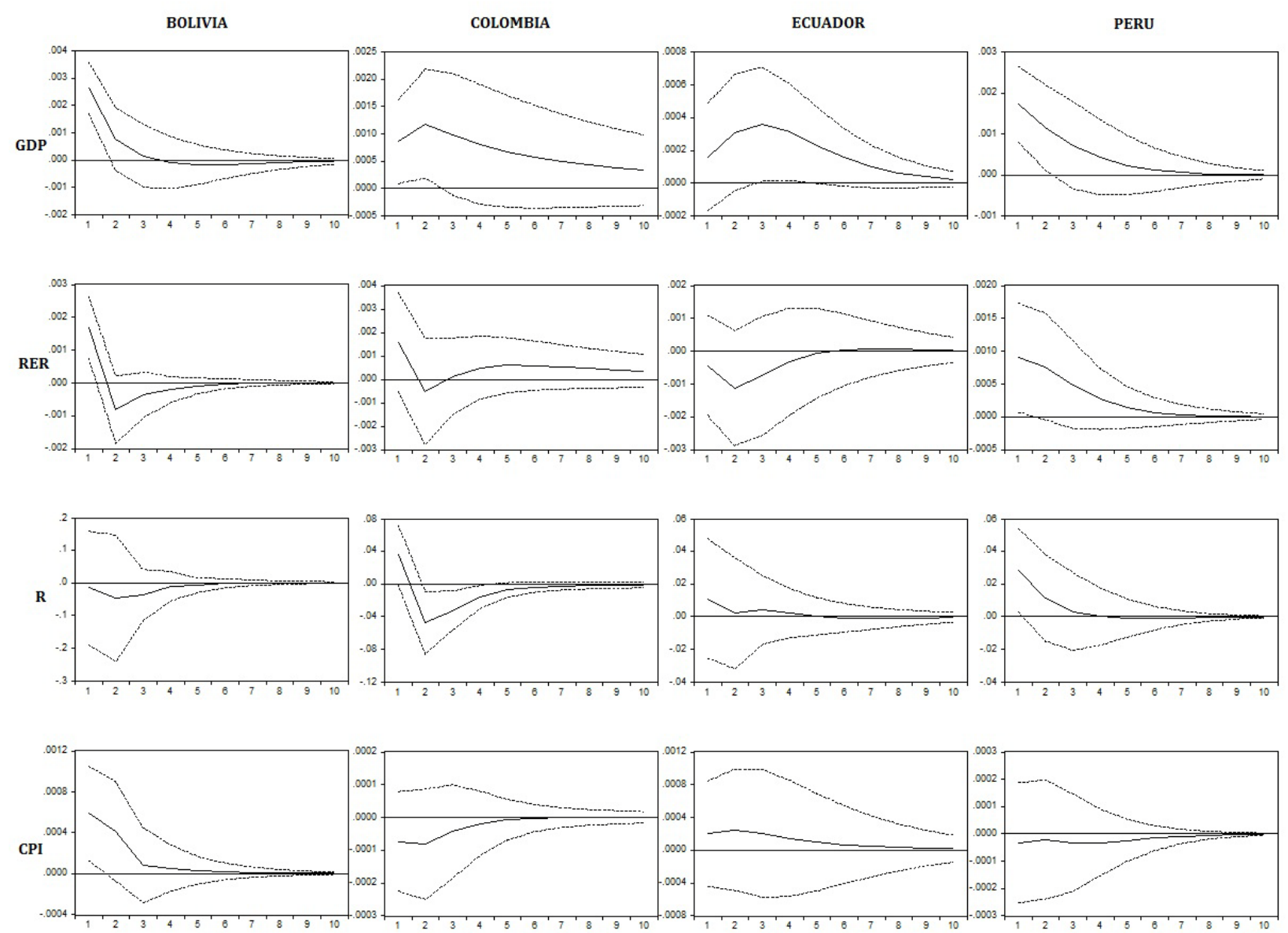

Figure 2. Impulse Response Functions to a Commodity Prices Shock during the period 2000-201031

${ }^{28}$ This is a short-term analysis and therefore only short term restrictions are applied (i.e., this is a nonrestricted SVAR analysis).

${ }^{29}$ The El Niño/La Niña-Southern Oscillation, or ENSO, is a quasiperiodic climate pattern that occurs across the tropical Pacific Ocean roughly every five years.

${ }^{30}$ Bolivia was not affected by the El Niño-Southern Oscillation because it is landlocked.

${ }^{31}$ Impulse-response figures have been obtained from SVAR models computed with monthly data which sources are the International Monetary Fund, Inter-American Development Bank and each country's Central Bank. 
During the 2000's (See Figure 2.), all CAN countries respond positively and significantly to the innovation as expected. Bolivia's production (GDP) is particularly sensitive (i.e., $20 \%$ of their output fluctuation is explained by the shock) because it is the second most open economy within the bloc (See Figure A.I ${ }^{32}$ ) and the Natural Gas Boom of 2002 affected it particularly (Bolivia along with Ecuador are hydrocarbon exporters - See Figure A.II -). The aggregate demand disturbance also increases price levels (CPI); interest rates $(R)$ do not react because there is no price stability commitment, and thus, the real exchange rate (RER) appreciates, reducing competitiveness.

Colombian and Peruvian output (GDP) also rise after the shock (i.e., respectively $7 \%$ and $10 \%$ of their output fluctuation is explained by the shock). But, in contrast to Bolivia, their price level does not go up because, by the 2000's, these countries have adopted an inflation targeting objective. In their case, interest rates $(R)$ increase to maintain stabilized inflation (i.e., respectively $10 \%$ and $4 \%$ of their interest rates variation is explained by the shock). In the Peruvian case, the adjustment also takes place through the exchange rate (RER) (managed float regimen).

Table 1. Variance Decomposition further to a Commodity Price Shock ${ }^{33}$

\begin{tabular}{c|cc|cc|cc|cc} 
& \multicolumn{2}{|c|}{ BOLIVIA } & \multicolumn{2}{|c|}{ COLOMBIA } & \multicolumn{2}{c|}{ ECUADOR } & \multicolumn{2}{c}{ PERU } \\
\hline GDP & $\mathbf{1 9 9 3}$ & $\mathbf{2 0 0 0}$ & $\mathbf{1 9 9 3}$ & $\mathbf{2 0 0 0}$ & $\mathbf{1 9 9 3}$ & $\mathbf{2 0 0 0}$ & $\mathbf{1 9 9 3}$ & $\mathbf{2 0 0 0}$ \\
\hline 1 & 2,93 & 21,68 & 0,77 & 3,81 & 0,16 & 0,72 & 0,52 & 10,30 \\
2 & 7,26 & 18,04 & 1,06 & 6,42 & 0,13 & 2,50 & 8,00 & 10,21 \\
6 & 10,31 & 15,99 & 1,03 & 7,18 & 0,16 & 7,29 & 12,52 & 9,64 \\
12 & 10,36 & 16,01 & 1,03 & 7,11 & 0,16 & 7,53 & 12,85 & 9,61 \\
RER & & & & & & & & \\
1 & 3,03 & 9,52 & 4,20 & 1,71 & 2,09 & 0,25 & 0,11 & 3,55 \\
2 & 2,61 & 10,68 & 5,96 & 1,63 & 1,67 & 1,27 & 0,12 & 5,27 \\
6 & 2,74 & 11,03 & 7,22 & 1,80 & 2,30 & 1,39 & 2,62 & 6,11 \\
12 & 2,79 & 11,03 & 7,20 & 2,12 & 2,30 & 1,37 & 3,05 & 6,11 \\
$\mathbf{R}$ & & & & & & & & \\
1 & 0,00 & 0,02 & 0,38 & 2,85 & 2,94 & 0,28 & 0,03 & 3,73 \\
2 & 0,05 & 0,21 & 0,33 & 7,24 & 4,34 & 0,28 & 0,08 & 3,47 \\
6 & 0,50 & 0,34 & 0,65 & 9,71 & 4,39 & 0,31 & 0,23 & 3,31 \\
12 & 0,50 & 0,34 & 0,65 & 9,70 & 4,39 & 0,31 & 0,42 & 3,31 \\
CPI & & & & & & & & \\
1 & 0,55 & 4,88 & 11,83 & 0,71 & 1,07 & 0,30 & 0,41 & 0,07 \\
2 & 0,83 & 6,85 & 9,19 & 1,29 & 4,34 & 0,50 & 1,58 & 0,08 \\
6 & 0,98 & 6,94 & 7,52 & 1,45 & 4,23 & 0,64 & 4,50 & 0,23 \\
12 & 1,03 & 6,95 & 7,44 & 1,45 & 4,23 & 0,64 & 4,97 & 0,23
\end{tabular}

\footnotetext{
${ }^{32}$ In Appendix4.

33 Variance Decomposition comes from SVAR models computed with monthly data which sources are the International Monetary Fund, Inter-American Development Bank and each country's Central Bank.
} 
Even if Ecuador is the most open economy within the CAN (See Figure A.I), only 6\% of her output (GDP) increase is explained by the shock because the dollarization of her economy reduces its competitiveness in relation to her partners. Ecuadorian price levels (CPI) do not react after the aggregate demand fluctuation; this would seem to evidence that the dollarization system has indeed imported credibility.

\subsubsection{A positive USA monetary policy shock}

During the 1990's, all CAN economies had a low degree of international financial integration (See Figure A.III ${ }^{34}$ ), therefore, there are not significant responses following a USA rates innovation during this period, as illustrated by Figure 3. By the end of the century, this situation has changed drastically, and, by the 2000's, the CAN economies have become more financially integrated, making their responses to the analyzed shock significant and interpretable during the 2000's.
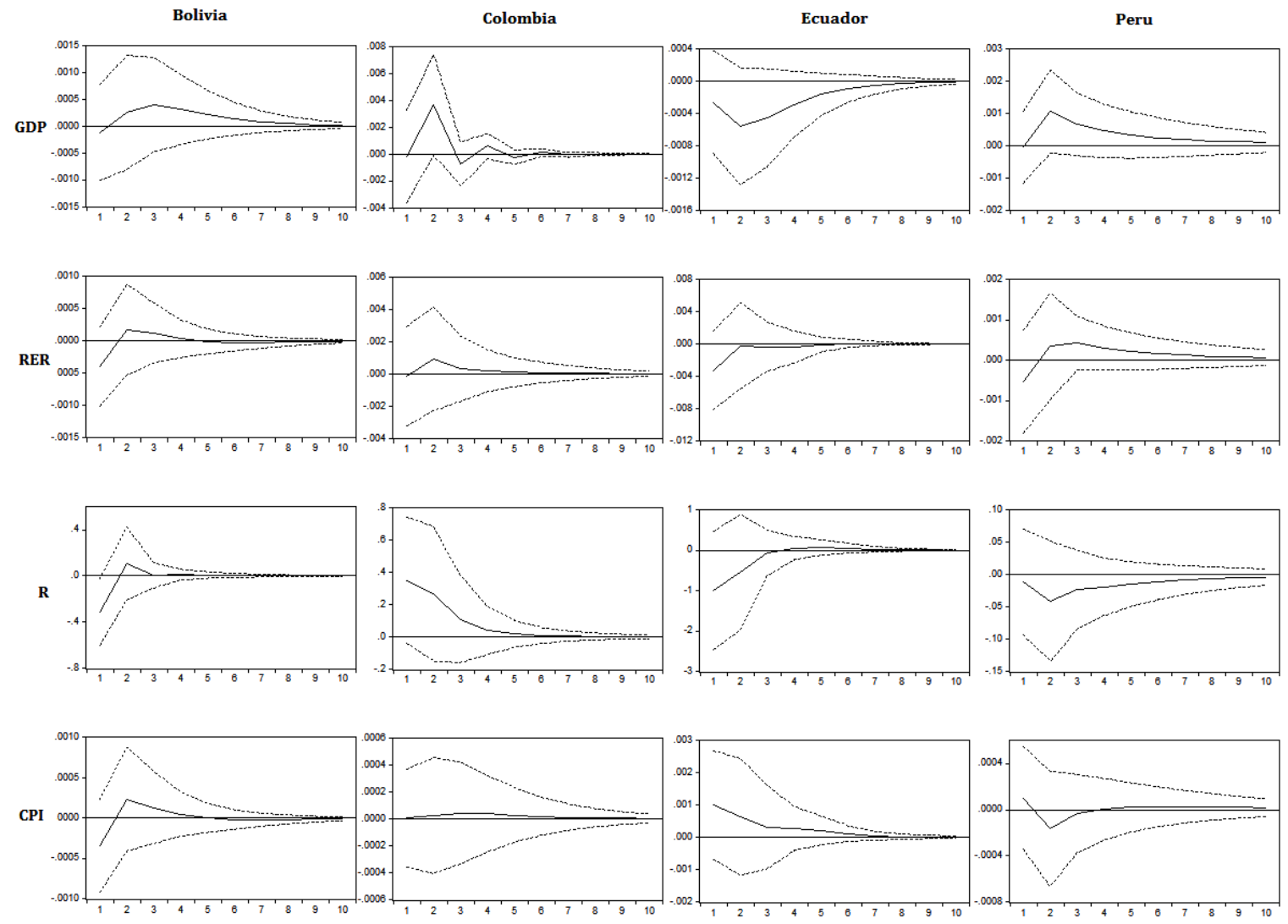

Figure 3. Impulse Response Functions to a USA Interest Rate Shock during the period 1993-200035

\footnotetext{
${ }^{34}$ In Appendix4.

${ }^{35}$ Impulse-response figures have been obtained from SVAR models computed with monthly data which sources are the International Monetary Fund, Inter-American Development Bank and each country's Central Bank.
} 
Theoretically, an increase in USA rates causes depreciation of domestic currency ${ }^{36}$ (Kim and Roubini, 2000). If depreciation is not possible, because of fixed rates or currency board agreements, the price level of Latin American securities should increase, making local interest rates rise. If the exchange rate adjusts fully and instantaneously, no changes in macroeconomic variables should be observed. When this is not the case, CAN members' output and prices may react - decrease (Canova, 2005). These reactions depend on the existing exchange rate regime. Fixed (dollarization) and quasifixed (crawling band) regimes are expected to be directly impacted by USA monetary policy because nominal exchange rates cannot adjust. Therefore a rise in Bolivian and Ecuadorian interest rates is expected after the positive USA shock. On the other hand, countries with flexible regimes (managed float) at the time - Colombia and Peru - are likely to adjust their exchange rate after the shock. The results, as illustrated in Figure 4, differ from those expected, the specific reasons are mentioned below.
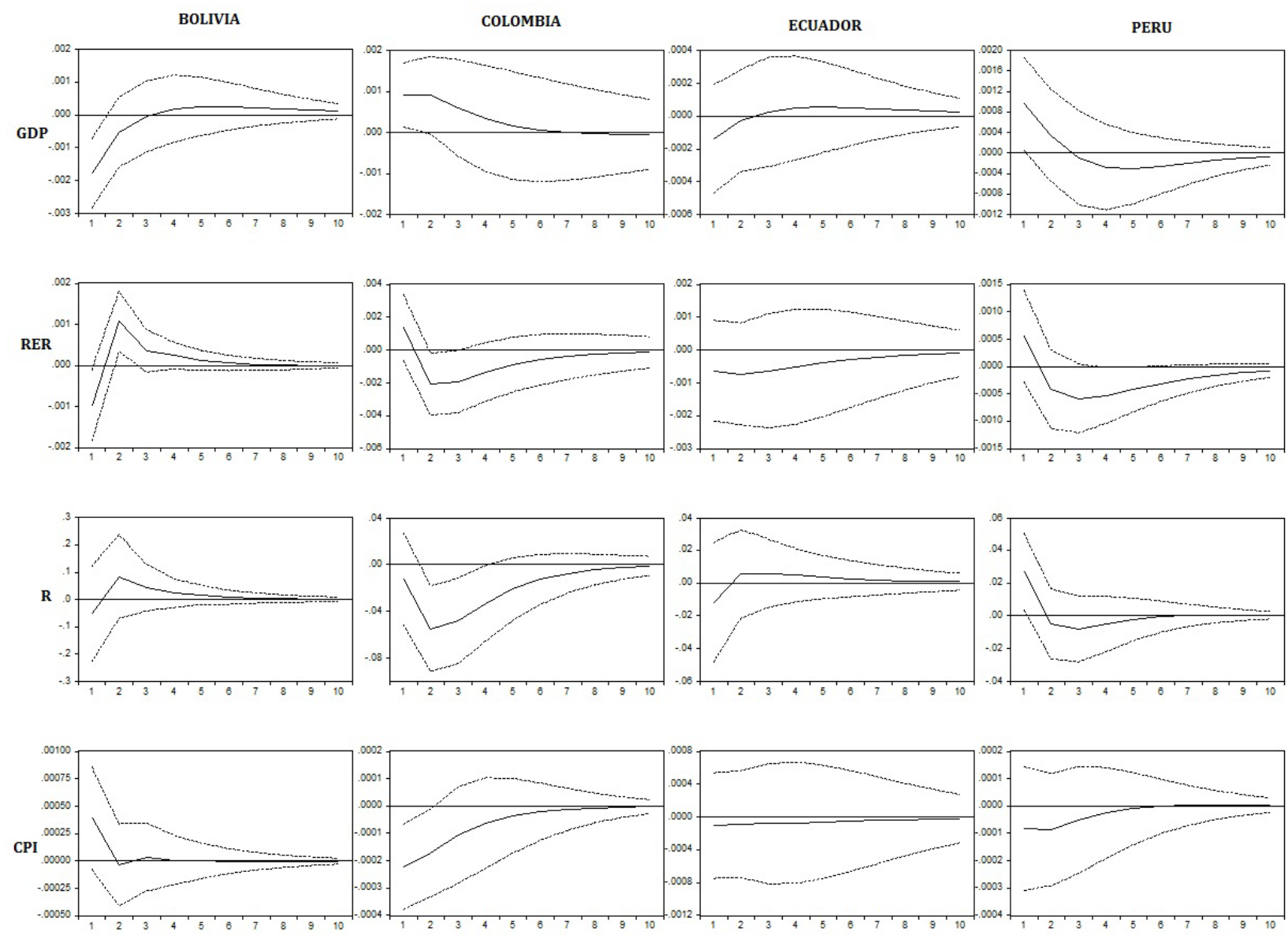

Figure 4. Impulse Response Functions to a USA Interest Rate Shock during the period 2000-201037

36It is more attractive to invest in USA than in Bolivia causing capital outflows and depreciation pressures.

${ }^{37}$ Impulse-response figures have been obtained from SVAR models computed with monthly data which sources are the International Monetary Fund, Inter-American Development Bank and each country's Central Bank. 
Bolivia's case during the 2000's is as follows: the rise in USA interest rates depreciates the boliviano (i.e., the Bolivian exchange rate (RER) decreases ${ }^{38}$ ) $-7.5 \%$ of the exchange rate fluctuation is due to the shock. Capital outflows lead to decline in output (GPB), and the interest rates (R) do not react because no measure is taken to boost the economy. The lack of reaction of Bolivia's interest rate is justified by the monetary authority's decision to keep low interest rates as part of the economy's "Bolivianizacion ${ }^{39 " . ~ I n ~ t h i s ~ c a s e, ~ a s ~ t h e ~ i n t e r e s t ~ r a t e ~ c a n n o t ~ r e a c t ~ d u e ~ t o ~ t h i s ~ p o l i c y, ~ t h e ~ a d j u s t m e n t ~ i s ~}$ achieved by output which decreases significantly and immediately after the shock (i.e., $8.35 \%$ of the decline in output is explained by the shock a month later).

The USA interest rate rise has an immediate impact on Colombia's interest rate $(R)$, which fluctuates by $10 \%$ a month after the shock. The interest rate increase reduces the price level (CPI) and does not entirely limit capital outflows because the exchange rate (RER) devaluates. This adjustment mechanism is possible since in 2001 Colombia adopted an inflation targeting objective and a managed float regimen. Output (GDP) does not react in the short-term to capital outflows.

Ecuador does not show significant reactions (a result which converges with Canova 2005). Three explanations can be proposed: first, one of the harsh financial regulation measures taken after the 1999 crisis is the gradual reduction of interest rates, a measure which is independent of external conditions; second, migrants' remittances have become the second source of Ecuadorians' income since 2001, offsetting capital outflows; and finally, by 2008, the Ecuadorian monetary authority has established capital controls and safeguards to avoid the economy's decapitalization ${ }^{40}$. Ecuador's case is special; further research on transmission channels in dollarized economies should be made in order to give more precise justifications.

In Peru, outflows create devaluation and inflation pressures, and, as an inflation targeting objective has been adopted since 2002, the domestic interest rates $(R)$ increase after the shock; this rise is effective because the price level (CPI) responses are not significant. The Peruvian exchange rate (RER) does not vary because the interest rate rises enough to limit the capital outflows.

\footnotetext{
38 The exchange rate is defined as the amount of foreign currency that one can obtain with one unit of domestic currency (i.e., dollars per domestic currency); therefore, a decrease in the exchange rate is interpreted as an depreciation of the domestic currency.

${ }^{39}$ Bolivianización is the name given to the set of measures taken for the reduction of informal dollarization and the recovery of national currency credibility; they seek to promote the use of the boliviano to the detriment of the dollar, in both economic and financial operations. (ASFI of Bolivia, Autoridad de Supervisión del Sistema Financiero Boliviano)

40 Because of dollarization, the Ecuadorian monetary authorities cannot devaluate the currency as an adjustment mechanism, therefore, they took alternative measures to assure liquidity.
} 
Table 2. Variance Decomposition further to a USA Interest Rate Shock ${ }^{41}$

\begin{tabular}{c|cc|cc|cc|cc} 
& \multicolumn{2}{|c|}{ BOLIVIA } & \multicolumn{2}{c|}{ COLOMBIA } & \multicolumn{2}{c|}{ ECUADOR } & \multicolumn{2}{c}{ PERU } \\
\hline GDP & $\mathbf{1 9 9 3}$ & $\mathbf{2 0 0 0}$ & $\mathbf{1 9 9 3}$ & $\mathbf{2 0 0 0}$ & $\mathbf{1 9 9 3}$ & $\mathbf{2 0 0 0}$ & $\mathbf{1 9 9 3}$ & $\mathbf{2 0 0 0}$ \\
\hline 1 & 0,10 & 8,35 & 0,01 & 4,03 & 0,91 & 0,54 & 0,01 & 3,33 \\
2 & 0,41 & 6,59 & 4,97 & 4,62 & 3,73 & 0,41 & 3,51 & 2,76 \\
6 & 1,79 & 5,97 & 5,06 & 3,18 & 6,13 & 0,50 & 4,26 & 2,97 \\
12 & 1,83 & 6,15 & 5,06 & 2,69 & 6,16 & 0,58 & 4,21 & 3,13 \\
RER & & & & & & & & \\
1 & 2,31 & 3,80 & 0,01 & 1,40 & 2,46 & 0,52 & 0,97 & 1,33 \\
2 & 2,20 & 7,44 & 0,48 & 3,88 & 1,95 & 0,79 & 1,21 & 1,85 \\
6 & 2,25 & 7,82 & 0,51 & 6,09 & 1,83 & 1,16 & 1,94 & 4,88 \\
12 & 2,27 & 7,82 & 0,51 & 5,81 & 1,83 & 1,20 & 1,98 & 5,20 \\
$\mathbf{R}$ & & & & & & & & \\
1 & 6,38 & 0,27 & 4,33 & 0,30 & 2,51 & 0,31 & 0,11 & 3,97 \\
2 & 6,46 & 0,84 & 5,86 & 5,28 & 3,18 & 0,37 & 1,12 & 3,36 \\
6 & 6,39 & 1,05 & 6,04 & 10,55 & 3,18 & 0,51 & 1,63 & 3,58 \\
12 & 6,39 & 1,05 & 6,04 & 10,54 & 3,18 & 0,52 & 1,68 & 3,58 \\
$\mathbf{C P I}$ & & & & & & & & \\
1 & 2,00 & 2,10 & 0,00 & 6,02 & 1,93 & 0,08 & 0,28 & 0,43 \\
2 & 2,43 & 2,04 & 0,02 & 7,14 & 2,18 & 0,10 & 0,78 & 0,71 \\
6 & 2,56 & 2,05 & 0,13 & 7,70 & 2,36 & 0,14 & 0,68 & 0,82 \\
12 & 2,57 & 2,05 & 0,14 & 7,71 & 2,36 & 0,15 & 0,70 & 0,82
\end{tabular}

\subsection{Correlation Analysis of the Responses}

To measure the symmetry in the response of CAN countries to external shocks, as in Gimet (2007), a correlation analysis of countries' significant responses is used in order to assess the compliance of the Andean Community of Nations with one OCA criteria (i.e., "Similarity of external shocks to which the different countries are exposed"), and the evolution of the bloc in this respect in two different periods of time (i.e., the 1990's and the 2000's).

Table 3 illustrates the results. In general, the responses within the CAN members are significantly higher during the 2000's than during the 1990's, especially in response to a USA interest rate shock.

On the one hand, regarding the positive American monetary policy shock and if we compare the responses in the two periods analyzed, the results evidence that, the real GDP response correlations between CAN members increase from about $56 \%$ to $91 \%$ only 6 months after the shock. In the same way, domestic interest rates and money demand responses increase from about 55\% to $81 \%$ and from $55 \%$ to $79 \%$, respectively, six months after the same shock. These results evidence that the adoption of macroeconomic convergence goals by the CAN - the gradual attainment of single-digit annual rates (inflation criteria - May 1999); and, not exceeding the 3\% of GDP in their

\footnotetext{
${ }^{41}$ Variance Decomposition comes from SVAR models computed with monthly data which sources are the International Monetary Fund, Inter-American Development Bank and each country's Central Bank.
} 
non-financial public sector deficit (fiscal convergence criteria - June 2001) - has contributed to a positive evolution towards economic integration. Only real exchanges rate responses decrease after 2000 (from about 77\% to 54\%) because, as pointed out in Table A.I, during the second period, the exchange rate regimes within the CAN became more dissimilar.

Table 3. Correlation Analysis

TABLE 3.1: Response correlation of GDP to external shocks

\begin{tabular}{|c|c|c|c|c|c|c|c|c|c|c|c|c|}
\hline & \multicolumn{4}{|c|}{6 months after the shock } & \multicolumn{4}{|c|}{9 months after the shock } & \multicolumn{4}{|c|}{12 months after the shock } \\
\hline & \multicolumn{2}{|c|}{ COMMODITIES } & \multicolumn{2}{|c|}{ USA } & \multicolumn{2}{|c|}{ COMMODITIES } & \multicolumn{2}{|c|}{ USA } & \multicolumn{2}{|c|}{ COMMODITIES } & \multicolumn{2}{|c|}{ USA } \\
\hline & 1993 & 2000 & 1993 & 2000 & 1993 & 2000 & 1993 & 2000 & 1993 & 2000 & 1993 & 2000 \\
\hline BO-CO & & & & & & & & & & & 4 & 0,77 \\
\hline BO-EC & & $-0,3$ & $-0,43$ & 1,00 & 0,63 & & & 1,00 & & 17 & $-0,68$ & 0,99 \\
\hline BO-PE & 0,4 & 0,94 & 0,72 & $-0,99$ & 0,53 & & & $-0,99$ & 0,61 & 0,90 & 0,82 & $-0,98$ \\
\hline CO-EC & 0,7 & 0,65 & $-0,60$ & $-0,82$ & $0,7 \varepsilon$ & & $-0,57$ & $-0,77$ & 0,80 & 0,92 & $-0,57$ & $-0,70$ \\
\hline $\mathrm{CO}-\mathrm{PE}$ & $-0,29$ & 0,62 & 0,72 & 0,85 & $-0,10$ & 0,77 & 0,73 & 0,78 & 0,02 & 0,80 & 0,72 & 0,72 \\
\hline EC-PE & $-0,68$ & $-0,07$ & $-0,81$ & $-1,00$ & $-0,29$ & 0,44 & $-0,83$ & $-1,00$ & $-0,07$ & 0,57 & $-0,86$ & $-1,00$ \\
\hline VERAGE & 0,52 & 0,50 & 0,57 & 0,91 & 0,51 & 0,58 & 0,62 & 0,89 & 0,49 & 0,63 & 0,65 & 0,86 \\
\hline
\end{tabular}

TABLE 3.2. Response correlation of RER to external shocks

\begin{tabular}{|c|c|c|c|c|c|c|c|c|c|c|c|c|}
\hline & \multicolumn{4}{|c|}{6 months after the shock } & \multicolumn{4}{|c|}{9 months after the shock } & \multicolumn{4}{|c|}{12 months after the shock } \\
\hline & \multicolumn{2}{|c|}{ COMMODITIES } & \multicolumn{2}{|c|}{ USA } & \multicolumn{2}{|c|}{ COMMODITIES } & \multicolumn{2}{|c|}{ USA } & \multicolumn{2}{|c|}{ COMMODITIES } & \multicolumn{2}{|c|}{ USA } \\
\hline & 1993 & 2000 & 1993 & 2000 & 1993 & 2000 & 1993 & 2000 & 1993 & 2000 & 1993 & 2000 \\
\hline $\mathrm{BO}-\mathrm{CO}$ & $-0,87$ & 0 & 0,75 & $-0,95$ & $-0,83$ & & 0,71 & $-0,93$ & $-0,82$ & 0,93 & 0,67 & $-0,92$ \\
\hline BO-EC & & & & -0 , & & & & & 0 & & 82 & $-0,24$ \\
\hline BO-PE & $-0,14$ & 0,39 & 98 & $-0,82$ & $-0,1$ & & & $-0,82$ & $-0,08$ & 0,30 & 0,95 & $-0,81$ \\
\hline CO-EC & $-0,91$ & 0,60 & 0,46 & 0,17 & $-0,89$ & 0,48 & 0,30 & 0,34 & $-0,88$ & 0,39 & 0,21 & 0,43 \\
\hline CO-PE & 0,08 & 0,0 & 0,60 & 0,93 & 0,12 & & 0,6 & 0,93 & 0,15 & 0,12 & 0,61 & 0,93 \\
\hline EC-PE & $-0,47$ & $-0,74$ & 0,92 & $-0,17$ & $-0,44$ & $-0,83$ & 0,83 & 0,06 & $-0,40$ & $-0,86$ & 0,76 & 0,22 \\
\hline VERAGE & 0,54 & 0,51 & 0,77 & 0,54 & 0,52 & 0,48 & 0,71 & 0,55 & 0,52 & 0,47 & 0,67 & 0,59 \\
\hline
\end{tabular}

TABLE 3.3. Response correlation of $R$ to external shocks

\begin{tabular}{|c|c|c|c|c|c|c|c|c|c|c|c|c|}
\hline & \multicolumn{4}{|c|}{6 months after the shock } & \multicolumn{4}{|c|}{9 months after the shock } & \multicolumn{4}{|c|}{12 months after the shock } \\
\hline & \multicolumn{2}{|c|}{ COMMODITIES } & \multicolumn{2}{|c|}{ USA } & \multicolumn{2}{|c|}{ COMMODITIES } & \multicolumn{2}{|c|}{ USA } & \multicolumn{2}{|c|}{ COMMODITIES } & \multicolumn{2}{|c|}{ USA } \\
\hline & 1993 & 2000 & 1993 & 2000 & 1993 & 2000 & 1993 & 2000 & 1993 & 2000 & 1993 & 2000 \\
\hline $\mathrm{BO}-\mathrm{CO}$ & $-0,42$ & 0,67 & $-0,54$ & $-0,87$ & $-0,44$ & 0,66 & $-0,54$ & $-0,79$ & $-0,45$ & 0,67 & $-0,53$ & $-0,77$ \\
\hline BO-EC & $-0,34$ & $-0,17$ & 0,67 & 0,87 & $-0,21$ & $-0,41$ & 0,67 & 0,86 & $-0,15$ & $-0,47$ & 0,67 & 0,86 \\
\hline BO-PE & 0,81 & $-0,24$ & $-0,60$ & $-0,85$ & 0,80 & $-0,39$ & $-0,39$ & $-0,82$ & 0,72 & $-0,44$ & $-0,28$ & $-0,79$ \\
\hline CO-EC & 0,79 & 0,59 & $-0,98$ & $-0,65$ & 0,63 & 0,38 & $-0,97$ & $-0,51$ & 0,56 & 0,32 & $-0,96$ & $-0,49$ \\
\hline CO-PE & $-0,32$ & 0,53 & $-0,33$ & 0,63 & $-0,34$ & 0,40 & $-0,53$ & 0,45 & $-0,29$ & 0,35 & $-0,60$ & 0,38 \\
\hline EC-PE & 0,04 & 0,91 & 0,16 & $-1,00$ & 0,16 & 0,92 & 0,32 & $-1,00$ & 0,07 & 0,92 & 0,38 & $-0,99$ \\
\hline AVERAGE & 0,45 & 0,52 & 0,55 & 0,81 & 0,43 & 0,53 & 0,57 & 0,74 & 0,37 & 0,53 & 0,57 & 0,71 \\
\hline
\end{tabular}


TABLE 3.4. Response correlation of CPI to external shocks

\begin{tabular}{|c|c|c|c|c|c|c|c|c|c|c|c|c|}
\hline & \multicolumn{4}{|c|}{6 months after the shock } & \multicolumn{4}{|c|}{9 months after the shock } & \multicolumn{4}{|c|}{12 months after the shock } \\
\hline & \multicolumn{2}{|c|}{ COMMODITIES } & \multicolumn{2}{|c|}{ USA } & \multicolumn{2}{|c|}{ COMMODITIES } & \multicolumn{2}{|c|}{ USA } & \multicolumn{2}{|c|}{ COMMODITIES } & \multicolumn{2}{|c|}{ USA } \\
\hline & 1993 & 2000 & 1993 & 2000 & 1993 & 2000 & 1993 & 2000 & 1993 & 2000 & 1993 & 2000 \\
\hline BO-CO & 0,83 & $-0,90$ & 0,73 & $-0,68$ & 0,85 & $-0,91$ & 0,60 & $-0,68$ & 0,84 & $-0,92$ & 0,49 & $-0,68$ \\
\hline BO-EC & $-0,89$ & 0,70 & $-0,51$ & $-0,65$ & $-0,90$ & 0,75 & $-0,36$ & $-0,58$ & $-0,89$ & 0,77 & $-0,32$ & $-0,54$ \\
\hline BO-PE & $-0,40$ & $-0,24$ & $-0,89$ & $-0,50$ & $-0,28$ & $-0,49$ & $-0,88$ & $-0,54$ & $-0,23$ & $-0,56$ & $-0,88$ & $-0,56$ \\
\hline CO-EC & $-0,53$ & $-0,94$ & $-0,62$ & 0,98 & $-0,61$ & $-0,94$ & 0,02 & 0,94 & $-0,64$ & $-0,93$ & 0,26 & 0,92 \\
\hline CO-PE & $-0,83$ & 0,28 & $-0,42$ & 0,97 & $-0,62$ & 0,61 & $-0,45$ & 0,98 & $-0,45$ & 0,68 & $-0,42$ & 0,98 \\
\hline EC-PE & 0,10 & $-0,42$ & 0,10 & 0,97 & $-0,01$ & $-0,79$ & $-0,06$ & 0,94 & $-0,10$ & $-0,86$ & $-0,09$ & 0,91 \\
\hline AVERAGE & 0,60 & 0,58 & 0,55 & 0,79 & 0,54 & 0,75 & 0,40 & 0,78 & 0,52 & 0,78 & 0,41 & 0,76 \\
\hline
\end{tabular}

On the other hand, and in contrast to the previous case, the improvement in symmetry reactions to commodity price shocks among CAN members is not as remarkable. The correlation analysis does not find notable changes in the symmetry of Real GDP and real domestic demand responses in the periods considered. This result is explained by the episodes of non-respect of the FTA agreement, like that of Ecuador after the subprime crisis of 2008: the member country placed tariffs on imports to avoid capital outflows and a dollar shortage, a shortage that could be crucial for its dollarized economy. Notwithstanding, domestic interest rates and money demand responses, a year after the shock, increase from about $37 \%$ to $53 \%$ and from $52 \%$ to $78 \%$, respectively. Certainly, even if the CAN FTA is not fully respected, the CAN's intrabloc trade has improved significantly (more than 500\% from 1993 to $2010^{42}$ - See Figure A.IV43 -) a fact that boosts CAN's commercial relations.

It is worth noting two interesting facts which emerged from the analysis. First, the responses are more similar in the face of a monetary policy shock than in the face of an international trade shock due to the fact that the adopted convergence criteria are predominantly monetary; and that, although the Andean Community of Nations was created in 1969, it has not yet adopted a common external trade policy. Within the bloc, Colombia and Peru have signed bilateral Free Trade Agreements (FTAs) with the United States, while Ecuador and Bolivia have negotiated with alternative markets in order to reduce their trade dependence on the North American country.

Second, after 1999 the similarities between CAN members have increased in pairs. Bolivia and Ecuador's responses are closer due to their similar political decisions. The same is true for those of Colombia and Peru ones because of the resemblance of their monetary regimes and objectives.

Finally, even if it cannot be concluded that the analyzed OCA criterion - similarity of external shocks - was achieved by the CAN, the results evidence that the applied convergence measures has

\footnotetext{
${ }^{42}$ See CAN Statistical Document SG/de 403 "42 años de Integración Comercial de Bienes de la Comunidad Andina" ${ }^{43}$ In Appendix 4.
} 
indeed increased the similarities within the bloc, endorsing the effectiveness of the group's convergence goals commitment.

\section{Conclusions and Discussion}

Using structural VAR models with short-term non-recursive restrictions, this article studies CAN members' reactions to two different shocks - a positive international trade shock and a USA positive monetary policy shock - and measures the similarity of the obtained responses in two periods (the 1990's and the 2000's). Four major conclusions can be drawn from the analysis. First, results highlight the vulnerability of the CAN economies to international shocks, a vulnerability that is considerably higher during the 2000's than during the 1990's. Second, as expected, the similarity of CAN economies' responses to external shocks evolved positively after commitment to convergence goals. Third, CAN economies' reactions are more similar in the face of a monetary policy shock than in the face of an international trade shock. And fourth, after 1999, the internal subgroups: EcuadorBolivia and Colombia-Peru, present the highest co-movements. In general, even if it cannot be concluded that the studied OCA criterion was achieved, this article evidences that the measures taken by the CAN have had a positive effect towards that aim.

The results of the investigation have an important policy implication: the commitment to meeting certain macroeconomic convergence objectives is far from be sufficient to achieve integration. If the region's aim is to form a MU, a long-run planning is required, along with the commitment of all members to prioritize the objectives of the bloc at the expense of their own. A common monetary and exchange rate mechanism is needed, and political differences must be overcome. Certainly, the lack of political agreements within the South American region has been their fundamental obstacle to advancing to a higher phase of economic integration, although, results evidence that the agreements reached by the group, regardless of their triviality, increase their similarities and enhance their objectives. Therefore, the most important recommendation is: start to work as a whole. 


\section{APPENDIX 1}

Consider that the economy is described by the structural form equation:

$$
B Y_{t}=\sum_{i=1}^{q} A_{i} Y_{t-i}+\varepsilon_{t}
$$

Where, $B$ is the contemporaneous interaction matrix (nxn), A is the dynamic interaction matrix (nxn), $\varepsilon_{t}$ represents the structural innovations vector (nx1) and $q$ is the number of retards. The structural innovations are supposed to be non-correlated (orthogonality assumption) and to have a unitary variance, then variance - covariance matrix $I_{n}=E\left(\varepsilon_{t} \varepsilon_{t}{ }^{T}\right)$ is a diagonal matrix ${ }^{44}$. The process is supposed stationary $|\mathrm{a}|<1 \forall i$.

The $\varepsilon_{t}$ innovations could be called "shocks" and they are economically identifiable (i.e., can be a monetary policy shock, fiscal policy shock, etc.), then, our interest is to analyze them.

B matrix captures simultaneity but, in practice, it is difficult to estimate (because of $\varepsilon_{t}$ 's endogeneity), to solve this problem it is useful to express the SVAR process in his reduced VAR canonical form ${ }^{45}$ :

$$
\begin{gathered}
Y_{t}=\sum_{i=1}^{q} B_{i}^{-1} A_{i} Y_{t-i}+B^{-1} \varepsilon_{t} \\
Y_{t}=\sum_{i=1}^{q} \Phi_{i} Y_{t-i}+v_{t}
\end{gathered}
$$

Where $v_{t}$, the statistical innovations vector, is a white noise with variance - covariance $E\left(v_{t} v_{t}{ }^{T}\right)=\Omega$.matrix is not subject to the orthogonality restriction. The statistical innovations can be estimated like the regression residuals of each canonical VAR equation (2) estimated by ordinary least squares (OLS).

We have:

Structural VAR representation:

$$
B Y_{t}=\sum_{i=1}^{q} A_{i} Y_{t-i}+\varepsilon_{t}
$$

Canonical VAR representation:

$$
Y_{t}=\sum_{i=1}^{q} \Phi_{i} Y_{t-i}+v_{t}
$$

Both representations are linked by:

44 This assumption makes it possible to isolate the effects of the shocks, which is important for economic experimentation.

45 The estimation of matrix B cannot be made directly due to the simultaneity. A way to address this problem is rewrite the system in his reduced form, which means, expressing the system in terms of endogenous and predetermined variables. 


$$
B v_{t}=\varepsilon_{t}{ }^{46}
$$

Then:

$$
\Omega=E\left(v_{t} v_{t}^{T}\right)=B^{-1} B^{-1^{T}} 47
$$

SVAR parameters must be recovered from those estimated in the canonical VAR representation. In this task, there is an identification problem (i.e., it is necessary to recover $n^{2}$ parameters from $n(n+1) / 2$ estimated parameters), then to achieve identification it is necessary to impose $n(n-1) / 2$ restrictions. There are several ways to impose restrictions ${ }^{48}$, this article will use the short run restriction for non recursive systems one ${ }^{49}$, and then, the restrictions will be imposed directly on $\mathrm{B}$ - the passage matrix - corresponding to some elements of the matrix set to zero.

To obtain the response impulse functions and the variance decomposition it is convenient to consider the MA $\wp$ ) repr esentation (Wold decomposition) of the canonical VAR form:

$$
Y_{t}=\sum_{i=1}^{q} \Phi_{i} Y_{t-i}+v_{t}
$$

All $\operatorname{VAR}(q)$ processes can be represented as a $\operatorname{VAR}(1)$ process, then it is equivalent to write ${ }^{50}$ :

$$
Y_{t}=\Phi Y_{t-1}+v_{t}
$$

Substituting recursively:

$Y_{t}=\Phi\left(\Phi Y_{t-2}+v_{t-1}\right)+v_{t}$

$Y_{t}=v_{t}+\Phi v_{t-1}+\Phi^{2}\left(\Phi Y_{t-3}+v_{t-2}\right)$

$Y_{t}=v_{t}+\Phi v_{t-1}+\Phi^{2} v_{t-2}+\Phi^{3} v_{t-3}+\cdots+\Phi^{\mathrm{j}} Y_{t-j}$

Due to the stationarity of the process $(|\Phi|<1)$ it is supposed that the effect of $\Phi^{\mathrm{j}} Y_{t-j}$ is negligible when $j \rightarrow \infty$, and therefore the process' convergence is assured allowing the

${ }^{46} v_{t}$ can be estimated by OLS, then $\widehat{\varepsilon_{t}}=\widehat{B} \hat{v}_{t}$

${ }^{47}$ Matrix $\Omega$ has $\mathrm{n}(\mathrm{n}+1) / 2$ distinct elements because it does not allow simultaneity.

${ }^{48}$ It is possible to impose short run restrictions (recursive systems or non-recursive systems), long run restrictions and sign and shape restrictions.

${ }^{49}$ Recursive systems use Cholesvky decomposition to build the passage matrix (B), the disadvantage is that this technique gets a triangular matrix and we lose simultaneity, therefore, we will use a nonrecursive system.

50 We have $Y_{t}=\sum_{i=1}^{q} \Phi_{i} Y_{t-i}+v_{t}$, if we call $Y_{t}=\left(Y_{t}, Y_{t-1}, \ldots, Y_{t-q+1}\right)^{T}$, then $Y_{t}=\Phi Y_{t-1}+v_{t}$ is equivalent, with $\Phi=\left[\begin{array}{ccc}\Phi_{1} & \Phi_{2} & \ldots \Phi_{q} \\ I_{d} & 0 & \ldots 0 \\ 0 & I_{d} & \ldots 0\end{array}\right]$ 
following generic representation of the moving average (MA) form of the canonical VAR model:

$$
Y_{t}=v_{t}+\Psi_{1} v_{t-1}+\Psi_{2} v_{t-2}+\Psi_{3} v_{t-3}+\cdots
$$

Or,

$$
Y_{t}=\sum_{i=0}^{\infty} \Psi_{\mathrm{i}} v_{t-i}
$$

\section{APPENDIX 2}

Canonical VECM representation:

$$
\Delta Y_{t}=\Phi_{1} \Delta Y_{t-1}+F Y_{t-1}+v_{t}
$$

Where $Y_{t}$ captures the variables, $v_{t}$ are the statistical innovations, $\Delta$ is the first difference operator, $F=M N, M$ captures the speed of adjustment, and $N$ are the cointegration relations.

From there one can define the structural form to compute the dynamic responses.

The structural VECM form is:

$$
B \Delta Y_{t}=A_{1} \Delta Y_{t-1}+K Y_{t-1}+\varepsilon_{t}
$$

Where $\mathrm{B}$ captures the non-recursive restriction and $\varepsilon_{t}$ are the structural innovations, again both representations are linked by:

$$
v_{t}=B^{-1} \varepsilon_{t}
$$




\section{APPENDIX 3: Stationarity Test.}

TABLE A3.1.- Dickey-Fuller Unit root test for period 1993M10-1999M12

\begin{tabular}{|c|c|c|c|c|}
\hline \multicolumn{5}{|c|}{ PERIOD 1993M10 - 1999M12 } \\
\hline & $\log (g d p)$ & $\log ($ rer $)$ & $\mathbf{R}$ & $\log (\mathbf{c p i})$ \\
\hline Bolivia & -1.195818 & -0.876495 & -3.447183 & -0.912321 \\
\hline Colombia & -1.953431 & -2.524393 & -1.765650 & -0.211973 \\
\hline Ecuador & -1.928598 & -0.184248 & -2.602409 & 0.350900 \\
\hline \multirow[t]{2}{*}{ Peru } & -2.966657 & -1.889594 & -2.867645 & -2.120464 \\
\hline & $\Delta \log (g d p)$ & $\Delta \log ($ rer $)$ & $\Delta \mathbf{r}$ & $\Delta \log (\mathbf{c p i})$ \\
\hline Bolivia & $-5.227369^{* *}$ & $-6.699077^{* *}$ & $-11.80100^{* *}$ & $-6.331363^{* *}$ \\
\hline Colombia & $-12.99784^{* *}$ & $-6.294559 * *$ & $-6.228563^{* *}$ & $-4.952112^{* *}$ \\
\hline Ecuador & $-4.465580^{* *}$ & $-10.15445^{* *}$ & $-8.206553^{* *}$ & $-6.736125^{* *}$ \\
\hline \multirow[t]{2}{*}{ Peru } & $-4.247143^{* *}$ & $-9.089047^{* *}$ & $-4.858265^{* *}$ & $-5.895540 * *$ \\
\hline & $\log \left(p_{-}\right.$ext $)$ & $\Delta \log \left(p_{-}\right.$ext $)$ & r_usa & $\Delta \mathbf{r}_{-} \mathbf{u s a}$ \\
\hline external var & -3.360108 & $-7.239514^{* *}$ & -2.526095 & $-3.906359^{*}$ \\
\hline
\end{tabular}

Note: one lag for the test, include constant and trend

${ }^{* *} 1 \%$ level $* 5 \%$ level

\section{TABLE A3.2.- Dickey-Fuller Unit root test for period 2000M01-2010M12}

\begin{tabular}{|c|c|c|c|c|}
\hline \multicolumn{5}{|c|}{ PERIOD 2000M01 - 2010M12 } \\
\hline & $\log (g d p)$ & $\log ($ rer $)$ & $\mathbf{R}$ & $\log (\mathbf{c p i})$ \\
\hline Bolivia & $-2,329665$ & $-1,472697$ & $-2,659841$ & $-1,585037$ \\
\hline Colombia & $-3,02766$ & $-3,073315$ & $-1,482032$ & $-1,161682$ \\
\hline Ecuador & $-2,990765$ & $-6.671611^{* *}$ & $-2,490711$ & $-6,818067^{* *}$ \\
\hline \multirow[t]{2}{*}{ Peru } & -3.011790 & -2.639293 & $-2,637973$ & $-1,948434$ \\
\hline & $\Delta \log (\mathrm{gdp})$ & $\Delta \log ($ rer $)$ & $\Delta \mathbf{r}$ & $\Delta \log ($ cpi $)$ \\
\hline Bolivia & $-6,027823^{* *}$ & $-11,63548^{* *}$ & $-17,15535^{* *}$ & $-8,798478^{* *}$ \\
\hline Colombia & $-3,646707^{*}$ & $-9,277732^{* *}$ & $-10,27159^{* *}$ & $-7,168414^{* *}$ \\
\hline Ecuador & $-5,487893^{* *}$ & $-4.665374^{* *}$ & $-11,02984^{* *}$ & $-5,313043^{* *}$ \\
\hline \multirow[t]{2}{*}{ Peru } & $-6,048642^{* *}$ & $-9,079419^{* *}$ & $-6,000287^{* *}$ & $-7,735354^{* *}$ \\
\hline & $\log \left(p \_e x t\right)$ & $\Delta \log \left(p_{-}\right.$ext $)$ & r_usa & $\Delta \mathbf{r}_{-} \mathbf{u s a}$ \\
\hline external var & $-3,040015$ & $-6,551838^{* *}$ & $-1,783895$ & $-4,700072^{* *}$ \\
\hline
\end{tabular}

Note: one lag for the test, include constant and trend

$* * 1 \%$ level $* 5 \%$ level 


\section{APPENDIX 4: Tables and Figures}

TABLE I: Exchange rate and monetary regimes in CAN countries (1991 and 2010)

\begin{tabular}{|c|c|c|c|}
\hline & $\begin{array}{c}\text { No } \\
\text { Independent } \\
\text { Currency }\end{array}$ & $\begin{array}{c}\text { Adjustable Peg } \\
\text { / Crawling } \\
\text { Bands }\end{array}$ & Managed Float \\
\hline \multicolumn{4}{|c|}{1991} \\
\hline \multicolumn{4}{|l|}{ No Independent Currency } \\
\hline Exchange Rate Target & & $\begin{array}{c}\text { Bolivia } \\
\text { Ecuador }\end{array}$ & \\
\hline Monetary Aggregates Target & & $\begin{array}{c}\text { Bolivia } \\
\text { Colombia }\end{array}$ & Peru \\
\hline \multicolumn{4}{|l|}{ Inflation Target } \\
\hline \multicolumn{4}{|c|}{2010} \\
\hline No Independent Currency & Ecuador & & \\
\hline \multicolumn{4}{|l|}{ Exchange Rate Target } \\
\hline Monetary Aggregates Target & & Bolivia & \\
\hline Inflation Target & & & $\begin{array}{c}\text { Peru } \\
\text { Colombia }\end{array}$ \\
\hline
\end{tabular}

Source: Each country’s Central Bank

\section{FIGURE A.I: CAN members' Evolution of Openness}

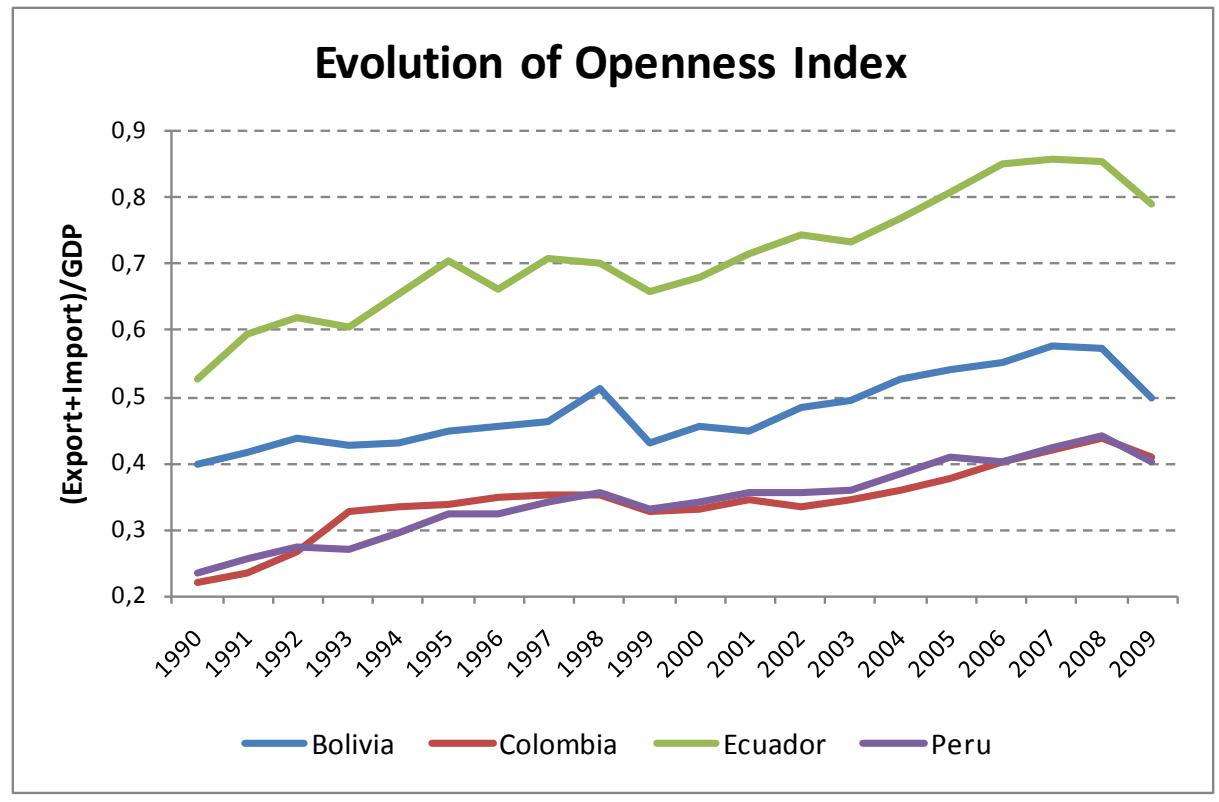

Source: World Bank statistics. 


\section{FIGURE A.II: CAN members' Exportations Structure (2008), \% share of each}

\section{sector relative to total exportation.}

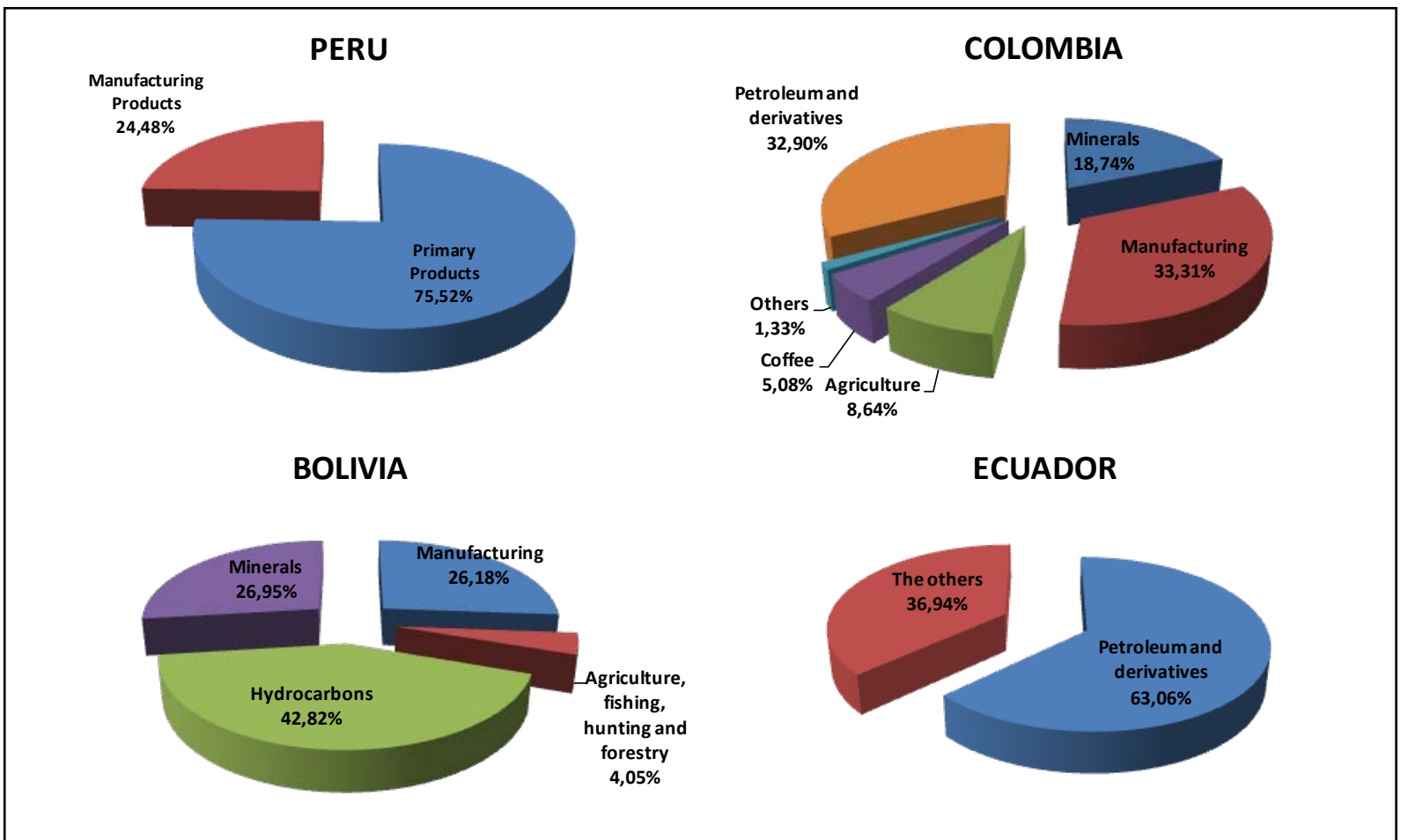

Source: Andean Economic Convergence Book 2009 (CAN publications), Peruvian Central Bank and Bolivian Statistical National Institute ${ }^{51}$.

51 Graphics have been constructed from several sources (Andean Economic Convergence Book 2009 (CAN's publications), Peruvian Central Bank and Bolivian Statistical National Institute) and exclusively for 2008 due to the data availability. 


\section{FIGURE A.III: Evolution of International Financial Integration}

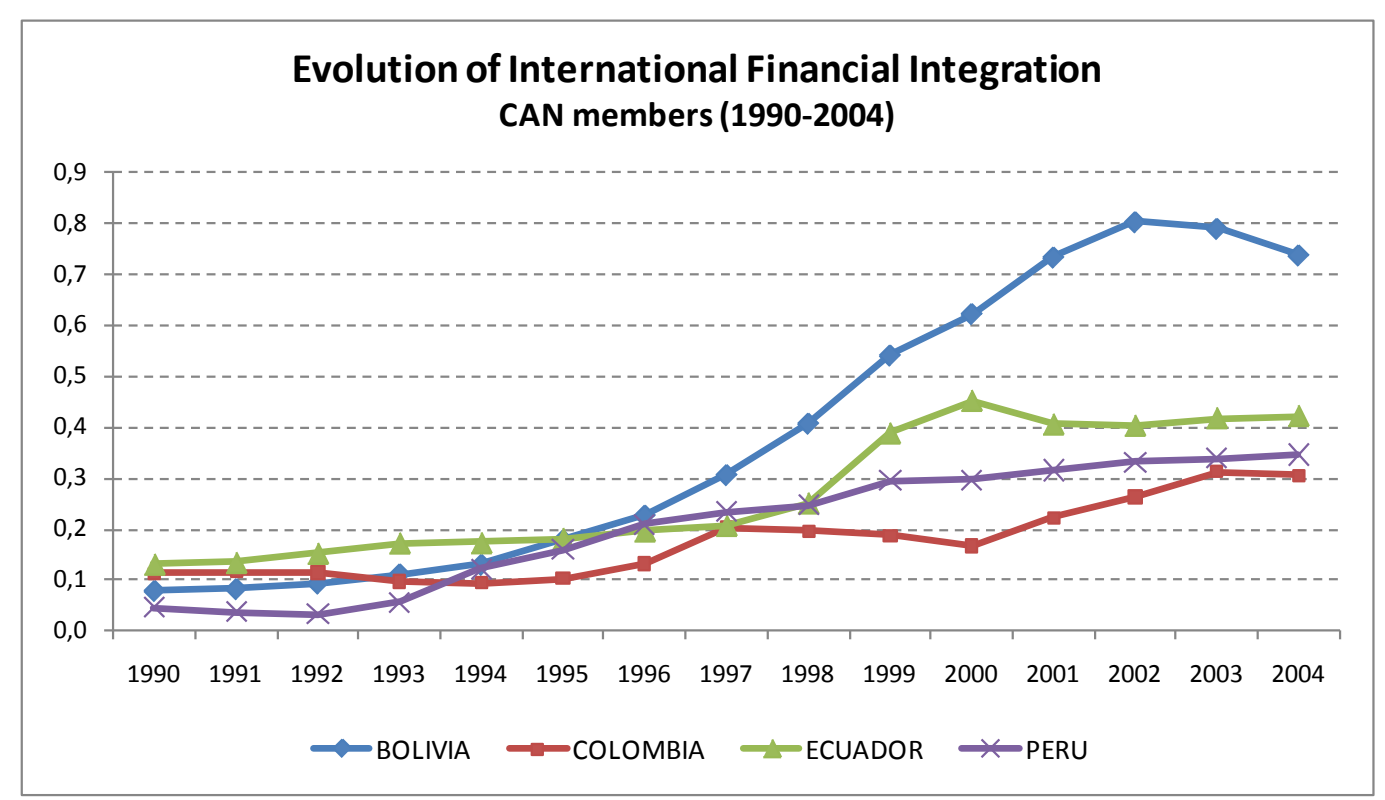

Source: Lane, Philip R. and Gian Maria Milesi-Ferretti (2010) database. IMF.

\section{FIGURE A.IV: CAN Intrablock Exportations (millions of US\$)}

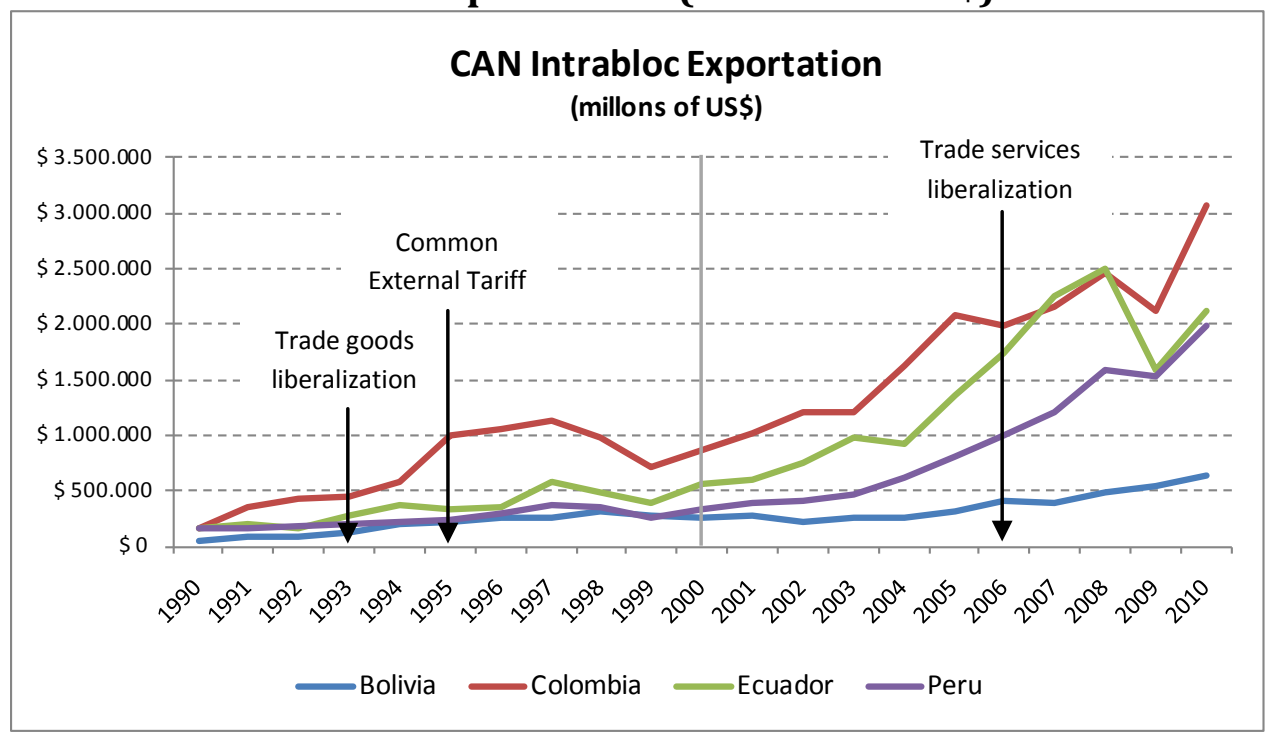

Source: CAN Statistical Document SG/de 403 “42 años de Integración Comercial de Bienes de la Comunidad Andina"52

52 Table drawn by the author from the Andean Community of Nations official statistics. CAN Statistical Document SG/de 403 "42 años de Integración Comercial de Bienes de la Comunidad Andina"1969-2010. 


\section{REFERENCES}

Allegret, Jean Pierre and Sand Alain. "Disentangling Bussiness Cycles and Macroeconomic Policy in Mercosur", Journal of Economic Integration 22 (2007): 482-514, 2007

Allegret, Jean Pierre and Sand Alain. "A. Does a Monetary Union protect against external shocks? An assessment of Latin American Integration", J Policy Model (2008).

Amisano, Gianni and Giannini Carlo. "Topics in Structural VAR Econometrics". 2nd edition, Springer (1997).

Andean Community of Nations Statistical Document SG/de 403 "42 años de Integración Comercial de Bienes de la Comunidad Andina" (1969-2010).

Balassa, Béla. "The Theory of Economic Integration". Homewood - Illinois, Irwin INC (1961).

Bruneau, Catherine and De Bandt Olivier. "La modélisation VAR Structurel: application à la politique monétaire en France", Banque de France - Direction Générale des Études 52 (1998).

Canova, Fabio. "The Transmission of US Shocks to Latin America", Journal of Applied Econometrics 20 (2005):229-251.

Cushman, David and Tao Zha. "Identifying Monetary Policy in Small Open Economy under Flexible Exchange Rate", Journal of Monetary Economics 39 (1997).

Edwards, Sebastian. "Monetary Unions, External Shocks and Economic Performance: A Latin American Perspective", International Economics and Economic Policy 3 (2006):225-247.

Eichengreen, Barry. "Does Mercosur Need a Single Currency ?", Center for International and Development Economics Research, Institute of Business and Economic Research (1998).

Enders, Walter. “Applied Econometric Time Series". USA, Jonh Winley \& Sons (1995).

Frenkel, Roberto and Rapetti Martin. "A Concise History of Exchange Rate Regimes in Latin America", Economics Department Working Paper Series - University of Massachusetts 97 (2010).

Gali, Jordi. "Does the IS-LM Model Fit us Postwar Data?," Quarterly Journal of Economics CVII (1992).

Gimet, Céline. "L'impact des chocs externes dans les économies du Mercosur: un modèle VAR Structurel”, Économie internationale 110 (2007):141-170.

Gimet, Céline. "Le projet d'union monétaire dans le Mercosur: Etude de la position actuelle des pays par rapport à une carte de critères de soutenabilité”, Cahiers économiques de Bruxelles 50 (2009): 73-97.

Hochreiter, Eduard and Siklos Pierre L. "Alternative exchange-rate regimes: The options for Latin America", North American Journal of Economics and Finance 13 (2002):195-211.

Hochreiter, Eduard et al. "Monetary Union: European Lessons, Latin American Prospects", The North American Journal of Economics and Finance, volume 13 (2002):297-321.

Lane, Philip R. and Gian Maria Milesi-Ferretti, "The External Wealth of Nations Mark II: Revised Extended Estimates of Foreign Assets and Liabilities, 1970-2004", IMF Working Paper, European I Department, WP/06/69 (2010).

Lane, Philip R. and Gian Maria Milesi-Ferretti. "International Financial Integration," IMF Working Paper, European I Department, WP/03/86 (2003).

Licandro Ferrando, Gerardo. “¿Un Área Monetaria para el Mercosur?”, University of California at Los Angeles, Banco Central del Uruguay (2003).

Lopes José and Tavares José, "Trade versus Currency Agreements: "Which Causes What to Economies?", European trade Study Group Meeting, Madrid (2003).

Kim, Soyoung and Nouriel Roubini. "Exchange Rate Anomalies in the Industrialized Countries: A Solution with a Structural VAR Approach," Journal of Monetary Economics 45 (2000):561-86.

Kopits, George. "Central European EU accession and Latin American integration: Mutual lessons in macroeconomic policy design", The North American Journal of Economics and Finance, volume 13 (2002):253-277.

Mackowiak, Bartosz. "External Shocks, USMonetary Policy and Macroeconomic Fluctuations in Emerging Markets," Journal of Monetary Economics 54 (2007):2512-20 
Paolo, Francesco. "What is EMU telling us about the properties of optimum currency areas?”, Journal of Common Market Studies (2005): 607-635.

Yeyati and Sturzenegger. "Is EMU a Blueprint for Mercosur ?", Cuadernos de Economia 110 (2000):63-69. 